\title{
A Study of the Integration of High School Library Specialties and Community Resources
}

\author{
Terng-wen Lin \\ Director of Library \\ National Jui-Fang Industrial Vocational High School \\ Taiwan
}

\section{A.Preface}

The interactive mechanisms of the senior and vocational high schools with one another as well as with the communities have been constructed recently in Taiwan. Every learning community as well as the high schools have worked together to advocate programs and activities such as online learning programs, backup programs for teacher resources, establishment of the instruction resource centers and seminars convened for teachers, etc. The cooperation and resource sharing between and among high schools can not only satisfy the requirements of education for the students within the communities, but also help achieve the goals of nature-oriented learning and development. In 2007, there are 45 learning communities in total, in which 484 high schools participate. The educational resources within each community support and meet the educational requirements of the local students so that the goal of constructing learning communities can be achieved. The construction of the cooperation mechanism to integrate resources among high schools will improve wide-scale educational quality and intensify the characteristic of each learning community.

The Ministry of Education in Taiwan enacts some related rules for the development of the community characteristic, in order to encourage establishment of the community resource sharing modes in every learning community, to integrate the educational resources within the community and to develop the community characteristic, so as to improve the educational quality in senior and vocational high schools within each community. The high schools within respective learning communities can work together to sketch out the plans to develop the integral 
characteristics of the learning communities, in accordance with the anthropogeography of each district, the educational resources and the status quo of the industrial development, so that the characteristic development projects can be proposed and executed cooperatively by the high schools. There have been 7 library-related development projects proposed and subsidized since 2004, including those of digital learning, and establishment of instruction resource centers.

This research will explore the cooperative theme projects in high schools' libraries, whether completed or ongoing, by which the methods and strategies of executing the projects can be reviewed. In addition, the cooperative modes and the application of the community resources within each project will be analyzed so that the views and opinions proposed can provide as a reference for those libraries which might desire to take up community cooperation.

\section{B. Aspect and purposes}

The expected research aspect and purposes in this study are as followed.

1. Research on the contents, methods and development strategies of the cooperative projects among school libraries in order to provide a guideline for topic selection and blueprint of libraries cooperation.

2. Explore the types and kinds of the senior and vocational high schools' libraries using the community resources, so as to provide as a reference for the libraries to choose and integrate the community resources.

\section{Procedures and Methods}

The implementation procedures and methods are as followed.

1.Explore the prize-winning community characteristic projects and the library-related programs in senior and vocational high schools in Taiwan during the period of 2004 to 2007 . 
2. Examine the websites of each community schools' characteristic projects in terms of contents analysis, and review the status quo of execution, strategies and accomplishments.

3. Sort out the related community-oriented studies and literature as well as the Internet data so as to perform the literature researches.

4. The conclusions and propositions will be proposed in the end as a reference for planning cooperation and integrating resources between and among senior and vocational high schools' libraries.

\section{The General Status Quo of Resource Integration between and among Senior and Vocational High Schools' Libraries in Taiwan.}

The community learning schools, the chosen community characteristic programs and the related projects in reference to senior and vocational high schools' libraries are sorted out as the following.

\begin{tabular}{|c|c|c|c|c|}
\hline $\begin{array}{l}\text { Nationwide High } \\
\text { School Community } \\
\text { System }\end{array}$ & $\begin{array}{l}\text { Cooperative } \\
\text { Schools }\end{array}$ & $\begin{array}{l}\text { Titles of } \\
\text { Cooperative } \\
\text { Projects } \\
\end{array}$ & $\begin{array}{l}\text { Project } \\
\text { Characteristics } \\
\text { and Strategies }\end{array}$ & $\begin{array}{l}\text { Community } \\
\text { Cooperative } \\
\text { Modes }\end{array}$ \\
\hline $\begin{array}{l}\text { Taoyuan District } \\
3(2004-2005)\end{array}$ & $\begin{array}{l}\text { Yang-mei High } \\
\text { School, etc. } 9 \\
\text { schools } \\
\text { included. }\end{array}$ & $\begin{array}{l}\text { Plans of } \\
\text { Integration } \\
\text { Platforms for } \\
\text { Internet } \\
\text { Learning }\end{array}$ & $\begin{array}{l}\text { Creativity } \\
\text { Curriculum } \\
\text { Design and } \\
\text { Employment of } \\
\text { Network Facilities } \\
\text { for the Purpose of } \\
\text { Inspiring Interests } \\
\text { for Learning }\end{array}$ & $\begin{array}{l}\text { Curriculum } \\
\text { development } \\
\text { classrooms; } \\
\text { Curriculum } \\
\text { Unit Material; } \\
\text { Mobile } \\
\text { Science Hall }\end{array}$ \\
\hline $\begin{array}{l}\text { Prescadores-Tainan } \\
\text { District } \\
2(2004-2005)\end{array}$ & $\begin{array}{l}\text { Tainan First } \\
\text { High School. } 6 \\
\text { schools } \\
\text { included. }\end{array}$ & $\begin{array}{l}\text { E Learning } \\
\text { Projects }\end{array}$ & $\begin{array}{l}\text { Building up } \\
\text { Learning } \\
\text { Platforms and } \\
\text { Sharing } \\
\text { Community } \\
\text { Cooperative }\end{array}$ & $\begin{array}{l}\text { the Elite } \\
\text { Grooming } \\
\text { Courses; } \\
\text { Geographical } \\
\text { Survey } \\
\text { Activities; }\end{array}$ \\
\hline
\end{tabular}




\begin{tabular}{|c|c|c|c|c|}
\hline $\begin{array}{l}\text { Miaoli } \\
\text { District(2006-2007) }\end{array}$ & $\begin{array}{l}\text { Miaoli High } \\
\text { School.5schools } \\
\text { included. }\end{array}$ & & $\begin{array}{l}\text { Schools' } \\
\text { Resources }\end{array}$ & $\begin{array}{l}\text { Astronomical } \\
\text { Observation } \\
\text { Activities; } \\
\text { Learning } \\
\text { Systems of } \\
\text { Network } \\
\text { Instruction }\end{array}$ \\
\hline $\begin{array}{l}\text { Taipei District } \\
6(2004-2005)\end{array}$ & $\begin{array}{l}\text { Shu-lin High } \\
\text { School, etc. } 6 \\
\text { schools } \\
\text { included. }\end{array}$ & $\begin{array}{l}\text { Distant } \\
\text { Learning } \\
\text { Centers } \\
\text { And The } \\
\text { allied }\end{array}$ & $\begin{array}{l}\text { Setting up } \\
\text { Instruction Data } \\
\text { Center for } \\
\text { Resource Sharing } \\
\text { cooperation-system }\end{array}$ & $\begin{array}{l}\text { Establishment } \\
\text { of E-learning } \\
\text { Teachers' } \\
\text { Creativity } \\
\text { Studios; }\end{array}$ \\
\hline $\begin{array}{l}\text { Keelung } \\
\text { District(2007-2008) }\end{array}$ & $\begin{array}{l}\text { Jui-fang High } \\
\text { School, etc. } 9 \\
\text { Schools } \\
\text { included. }\end{array}$ & $\begin{array}{l}\text { function of } \\
\text { library } \\
\text { cooperation }\end{array}$ & of library & $\begin{array}{l}\text { Constitution } \\
\text { of E-learning } \\
\text { Instruction } \\
\text { Data Centers; } \\
\text { Construction }\end{array}$ \\
\hline 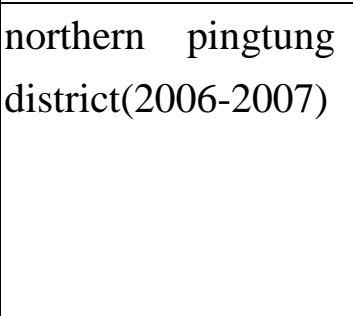 & $\begin{array}{l}\text { pingtung } \\
\text { High School, } \\
\text { etc. } 10 \text { Schools } \\
\text { included. }\end{array}$ & & & $\begin{array}{l}\text { of E-learning } \\
\text { Electronic } \\
\text { Instruction } \\
\text { Management } \\
\text { Systems }\end{array}$ \\
\hline $\begin{array}{l}\text { Keelung } \\
\text { District(2005-2006) }\end{array}$ & $\begin{array}{l}\text { Jui-fang High } \\
\text { School, etc. } 10 \\
\text { Schools } \\
\text { included. }\end{array}$ & $\begin{array}{l}\text { the present } \\
\text { and the past } \\
\text { of keelung } \\
\text { river and } \\
\text { harbor } \\
\text { e-learning } \\
\text { environment }\end{array}$ & $\begin{array}{l}\text { Creating Digital } \\
\text { Material for Local } \\
\text { Culture and } \\
\text { Engaging in } \\
\text { Various Kinds of } \\
\text { Visiting Activities }\end{array}$ & $\begin{array}{l}\text { Digital } \\
\text { Education } \\
\text { Center; } \\
\text { Material } \\
\text { Resource } \\
\text { Center; } \\
\text { Seminars } \\
\text { visiting } \\
\text { activities }\end{array}$ \\
\hline
\end{tabular}

The following we will have a discussion about those projects, from 2004 to 2007, have been accomplished or some in proceeding. Discussion will be made on three aspects, such as the choice of plan feature, action strategy and the utilization of community resources, to be specified as follows:

(I).The aspect of characteristic theme choice; 
1. The theme of allied function of library cooperation, to achieve the purpose of sharing community resources: such as "northern pingtung district" for instance, community school to establish cooperation-system of library, including the exchange of book-reading and lending, to share digital database and reading unit on network.

2. Regional culture or school's relative characteristic theme, establishing digital database for each individual library specialty: besides the book-lending cooperation via library, practically, there still regional culture or school characteristic related theme can be mutually developed. For instance keelung region (the present and the past of keelung river and harbor e-learning environment), each vocational or high school should be based on their local history and cultural feature to develop the specialy and digital database.

3. The theme of establishing e-learning center for remote area, to achieve sharing use of digital instruction material: (such as Miaoli District), each individual school in community can put their teaching curriculum on website, to make multi-media video instruction material, deliver over to website platform of digital instruction, by saving manpower on repeating duplication of teaching material, to increase student's learning interest and achievement.

(II).The aspect of action strategy:

1. To set up network of instruction material center, to share the community-school's digital instruction material and featured result: to gather the effect resulted in digital instruction material after the cooperation of each school, to organize community instruction material, providing a learning type of website for school, teacher, student and public in community.

2. To establish digital education center, to provide for digital teaching resources and teacher: to program digital learning curriculum, to hold training activities for teacher and volunteer, providing teacher with idea to merge in instruction material and of web-designing ability.

3. To set up an unified of learning platform: to consolidate each school's teaching website in community and data of class, both of teacher and student can be made with test on the network center, handing homework \& communication, etc.,

4. To hold various contest for community school: such as, to arrange web-designing exhibition for teacher \& student, through their cooperation and combined with community resources, to create learning atmosphere.

5. To establish allied library function: to make book's circulation more to the hands of teacher and student, to increase value of book-reading.

6. To arrange varied meetings for discussion and visiting activities: to breed 
mutual-care for teacher \& student, affinity ability to community, to enhance teacher and student the senses of humanism and natural surroundings.

7. To establish community learning groups and community-based e-paper: to be alternately fabricated by each school, to express their feature of school, and encourage community with mutual-care on education, eventually to manage community become a perpetual learning environment.

8. To set up network of reading group and column of thesis writing \& discussing: to establish network sharing platform, for the reading group could communicate at different place and time.

(III). The integration of community resources:

1.Assistance on regional culture industries: to promote benefit to the student: for instance, digital teaching material to be free supported by the organization of culture publication, to accelerate succeeding project.

2. College-allied strategy: to share the use of facilities, plan guidance, attend to case-study, etc., to fulfill the entire target on cooperation, development and consolidation of resources in community.

\section{F. Conclusions and suggestions}

In the so-called 21st E-century, the traditional closed campus has been replaced with the learning environment of multiplicity, openness, creativity, and information orientation. Therefore, in order to make schools as learning and living centers for the community, it is necessary for schools to include community resources, to develop their specialties, and to enlarge students' learning domains.

Under the objective of turning schools into learning centers for the community, school courses should be designed for the growth of students. Parents, teachers, and all walks of life should all participate together to form a supportive network and provide a abundant and boundless learning environment for students.

Besides, under the objective of putting community resources to good use, it is essential for the community to associate with schools and to provide manpower as well as funds for the development of schools. In returns, schools also open their facilities for the community and take part in community activities

The following are the conclusions and suggestions to the study of "A Study of the Integration of High School Library Specialties and Community Resources“ 
(1) Take the new cooperation theme options into consideration of the research on the local cultures.

Distance teaching resource center, digital learning, E-learning, digital instruction platform, allied cooperation system are the most popular unique themes in the cooperation of the community schools. In addition, we believe the community culture-featured history can also consider being incorporated into the new cooperation theme option by advancing the program to create the various collection features and digital archives of each school.

(2) Combine the local culture industries with the college resources to develop the community schools features.

We may seek to make the cooperation with the local culture industries and form an alliance with colleges to make the best use of the educational facilities resources in them, to bring out integrated community resources and develop the community features actively in the program.

(3) Create the teaching, learning and resource management platform in the remote or extensive learning community.

To share teaching resources and characteristic results, we should plan setting up the community digital resource platform to manage all kind of information, equipment and resources to provide the superior e-environment for the teachers and students. Because of the inconvenient traffic, the remote or extensive communities should develop digit-featured teaching and create the community digital learning platform to increase the curricular communication among the cooperative schools and provide the students the growth opportunity of self-learning.

(4) Promote the cooperation among the community schools system in libraries and focus on the development of digitalized collection.

Promote the cooperation among the community schools to achieve the expectant effects. The libraries in the high school and vocational school should develop the following strategies actively in the program:

1.develop the digitalized collection policy.

2.develop the virtual collection to construct the digital library to lead the trend of the information age.

3.participate in all kinds of "resources sharing league " to develop the library function effectively

(5) Accelerate the establishment of the e-learning environment in schools

Aid schools to set up e-learning environment by the community educational training. Make students and teachers in every school familiar with the basic ideas and operations about e-learning. Meanwhile, expand the field of the 
digital curriculum to make the community a real network college.

(6)Complete the characteristic teaching materials to achieve the goal of the community e-college.

In the progress of the program, integrate the unique subjects into the assistant teaching course of the distance learning to provide the best mode of online learning for students. 